\title{
Language and the current challenges in the South African school system
}

\author{
Elliot Mthembeni Mncwango' \\ Department of General Linguistics, University of Zululand \\ emncwan@pan.uzulu.ac.za
}

\begin{abstract}
The paper discusses the current challenges facing the school system in South Africa with regard to language, and the role schools can play to achieve the government's objective of multilingualism. Schools are viewed as the most fertile ground for the promotion of multilingualism, as they are attended by learners from different linguistic and cultural backgrounds. What obtains in many schools, especially former Model C schools, is that most of them have not included indigenous African languages in their school curricula. The few that have, offer them at second or third language level - just 'isiZulu for communication', etc. In this way, only the language for communication purposes is taught, which does not mean full literacy in the language, or cultural integration.

The argument is that with a willing heart on the part of the School Governing Body (SGB), as well as the School Management Team (SMT), language could be used as a tool to integrate learners. This, it is argued, does not obtain in the majority of urban schools. The paper is part of a study which was conducted in 2007. It is, therefore, underpinned by empirical evidence which was solicited from urban (English and Afrikaans medium), and rural (English and isiZulu medium) schools.
\end{abstract}

Keywords: Language, schools, South Africa, South African Schools

\section{Introduction}

This paper attempts to establish whether the government policy on multilingualism is effective, and whether schools are able to implement it. It also looks at whether schools can play a role in promoting the use of indigenous African languages. The current challenges in the South African school system are discussed, together with some suggestions.

\section{The language situation in South Africa}

To date, management of linguistic diversity in post-apartheid South Africa has been made problematic by the lack of a clearly defined language policy, leading to the use of English and Afrikaans as the most dominant languages in the socioeconomic and political domains of our society.

The Language-in-Education Policy (2004) promotes the use of learners' first language and English as medium of instruction in most schools.

This is due to the strong awareness of the need to intensify efforts to develop the previously marginalised indigenous languages and to promote multilingualism if South Africans are to be liberated from undue reliance on the utilisation of non-indigenous languages as the dominant, official languages of the state.

What we observe in most schools is that linguistic diversity is not embraced. This is evident in the dominance of English and the absence of the African culture in schools with diverse cultures. The so-called African culture is neither practised nor heard of. For instance, youngsters are taught to look elders in the eyes - this in the name of keeping eye contact. When one goes for an interview one is expected to keep eye contact, to remain standing until one is offered a seat, etc. This is foreign to the African culture. In the African culture eye contact is avoided by the younger interlocutor in a conversation. This is also applied where the interlocutor is higher in status, although younger in age. These African cultural practices are downplayed in urban schools.

\section{Semi-literacy in indigenous African languages}

Most African learners in the former Model C schools can't read or write in their first languages, with the exception of those who study these languages in the schools where they are offered. This is not in line with additive multilingualism, as it entails, inter alia, that speakers of the languages are able to read and write in the languages, for literacy in the languages to be realised.

Indigenous languages are spoken widely in South Africa today, and have always been in the past, although they were not accorded the same official status as English and Afrikaans. Although the latter were minority languages, they were developed to the extent that much literature is available in these languages even today. The two languages had been and are still the languages of documentation in courts of law, hospitals, clinics, etc. Although some institutions, like a few banks, have started using indigenous African languages, others are still oblivious of the use of these languages by most of their customers/clients.

I. Elliot Mcwango is a Lecturer in the Department of General Linguistics at the University of Zululand, South Africa. 


\section{The promotion of additive multilingualism in schools}

Although the government has expressed emphatically the call for the promotion of and use of indigenous languages nationally, there is no evidence that the policy on multilingualism is in force in schools. In fact, there seems to be no change at all aimed at increasing the developing indigenous languages or to accord them a status equivalent to that given to English and Afrikaans, functionally. The two have been languages of national use and as such have been developed to suit this purpose.

Before the first democratic rule in South Africa, English and Afrikaans were the only media of instruction, despite the fact that the majority of South Africans were not competent in them, which made education through these media an uphill struggle. Despite this fact, second language speakers had to compete with first language speakers of the language at interviews, etc. Worse still, these second language speakers came from disadvantaged backgrounds, where teachers had themselves received poor education, and were in many ways, quite frankly, ill-trained or unqualified to teach English or Afrikaans, or even to teach through these media. Buthelezi (1995) argues that under apartheid rule these schools had been run almost exclusively by Black non-native speakers of English who had often been unqualified or under-qualified for the task. In research conducted by Wildsmith (1992), cited in Buthelezi (1995), it was found that most non-standard features exhibited by the pupils were actually teacher-induced. All this resulted from the segregated and unequal education of the time, which actually limited the 'naturalistic environment' (Krashen, 1987) conducive to second-language learning by reducing the potential social interaction between second and first language speakers.

Banda (2000) reports that the Afrikaner nationalist government went on a deliberate campaign to uproot White English mother-tongue teachers from Bantu Education, thereby denying Black children authentic models of English and well-trained, experienced teachers. This still obtains, even today, as the problem of ill-trained teachers abounds in some schools, especially rural schools. As a result of this, it is not surprising that we get students who can't write even a coherent paragraph in English at university level.

Educational institutions in South Africa use mostly English as their medium of instruction, with some that use Afrikaans. Although this is done for socio-economic reasons, and to increase chances of employability, it denies indigenous languages a fair chance to be utilised as tools of wider communication in academic circles. The promotion of multilingualism in South Africa requires efforts that do not discount the knowledge that exists in societies where indigenous official languages are prominent (National Language policy Framework, 2002). If these languages cannot be fully utilised in South Africa, where will they be utilised? Roy-Campbell (200I) writes:

Despite the overwhelming evidence that the use of foreign languages negatively impacts the acquisition of school knowledge by the vast majority of African students, throughout most African countries the foreign languages continue to be afforded dominance in the educational sphere. The colonial imposition of these languages as the languages of knowledge that should be valued and as the languages of cultural capital has contributed to the naturalisation of English, French, or Portuguese as an indispensable part of what it means to be educated in many African countries. Those who are considered the knowers speak the language of power English, French, or Portuguese - while the knowledge of those who do not speak the language of power is devalued.

Although the status of indigenous African languages has been elevated to that of English and Afrikaans, there is the 'access paradox'. Janks (2000) questions how the education system can give all children access to the language of power, English, without also contributing to the dominance of English and the subsequent marginalisation of indigenous African languages.

\section{Language and identity}

More recently, many African children are said to struggle - both linguistically and in terms of their cultural identity - in previously White, Coloured and Indian English - medium schools (Young et al.: 1995). Luckett (1992) argues that these are both forms of subtractive multilingualism which occur when 'a second language is learned at the expense of the first language, which it gradually replaces.'

Also, some Afrikaans-only and English-only 'White' schools are now offering African languages such as isiXhosa or isiZulu as optional subjects. The token use of isiXhosa or isiZulu does not mean full integration of language groups. In practice, working-class children from Black and Coloured families cannot afford the high fees of these former 'Whites only' schools.

Also, contrary to the advocacy for multilingualism and the promotion of multilingualism, almost without exception, school application forms and other documents in South Africa have a 'Home Language' section. Ironically, despite the overwhelming evidence on multilingualism and government's additive bilingualism policy, it is still assumed and expected 
that South Africans are typically monolingual, using a 'Home Language' in their neighbourhoods. The argument is sometimes used by a school to deny a child entry on account of his/her 'home language' if it is deemed to differ from the medium of instruction of the school. In such a situation a child is 'encouraged' to enroll in another school.

\section{Language use and attitudes}

Research has shown that for political, socio-economic and educational considerations, those South Africans whose first languages are indigenous African languages tend to be multilingual. This is despite the attempts by the apartheid regime to divide people into unique linguistic communities, each with its own 'mother-tongue' education. Research has also shown that English and Afrikaans first language speakers tend to be at most bilingual. In a nutshell, Blacks' preference for English Medium of Instruction (EMOI) could be due to their quest to attain personal achievement in formal and professional spheres so as to have attributes of status and power denied them during apartheid (Banda, 2000).

Fanon (1967) describes ways in which language and its uses serve to reinforce the subjugated position of the Black colonial subject. Within this vein, those Africans who continually invoke the inadequacy of their languages for use in certain domains are impugning Africans' importance as human beings with a culture worthy of respect. Fanon (1967) argues that in the colonial experience, European languages and cultures were presented as superior to everything African. It is within this context that formal education has come to be associated with the European languages. Afolayan (1978) maintains that because the use of a foreign language as the medium of education is the norm in most postcolonial African countries, scholars and policy makers tend to equate education for the African with the knowledge of the European language.

\section{Resistance by some schools to transform in line with the prevalent diversity in South Africa}

All schools were founded in order that a particular educational purpose could be fulfilled in a particular community. The study found that all schools were founded solely to serve the interests of the communities within which they were built. It is important to remember that during apartheid there was the Group Areas Act which prohibited racial integration in residential areas. Surely, these schools served well the interests of their respective communities and the residents of the relevant towns.

However, with the phasing out of the Group Areas Act, people of all races were allowed to buy property anywhere, and to become rightful residents wherever they chose to be. When this happened, there were changes in the composition of the communities within which the schools were situated. As a result of this, almost all urban schools are attended by learners from all racial groups, with diverse cultures and languages. This being the case, one would expect the schools to incorporate this kind of diversity and reflect it in their school curricula.

This could be done by introducing indigenous languages to cater for the needs of African learners who enrol in urban schools, and who have become part and parcel of the communities within which the schools are situated, and whose interests they should serve. On the other hand, the diverse communities should ensure that the schools serve their own interests, and fight hard for transformation to take place. This currently does not obtain in most schools in South Africa, as Black parents have to take or leave the package as it was designed ages ago, which was not designed with them in mind. Those with a dissenting voice are quashed easily at parents' meetings, as they are in the minority.

Another observation my study makes is that the culture in most former Model $\mathrm{C}$ schools does not reflect community diversity, both inside and outside the schools. Black learners and parents who now subscribe to such schools have had to adapt in order to fit into the culture and philosophy of the schools.

\section{Conclusion}

The paper has attempted to highlight the current challenges associated with language and multilingualism in the South African school system. The reluctance to effect and reflect changes in the school curricula in line with the changes in demographics within the school, and in the community surrounding the school has been highlighted. The token introduction of indigenous African languages in certain schools has been discussed, as well as the consequences of that practice.

\section{Recommendations}

Although progressive policies on multilingualism have been promulgated, their implementation is lacking. In order for policies to be effective, they need to be sanctioned by government. In this way it would be easy to penalise the schools that do not implement them.

Also, there needs to be racial integration in terms of teachers in each school, particularly in urban EMOI and AMOI schools. A considerable number of these schools do not have Black teachers. Even those that have introduced indigenous African languages as optional languages have done so without employing even a single Black teacher who could take Inkanyiso, Jnl Hum \& Soc Sci 2009, I(I) 
charge of the language, as well as other subjects. This does not mean that non-Black teachers who teach indigenous languages are not qualified to do so, or that only a native speaker of a language can teach it with success. As a matter of fact, there are many highly qualified teachers who are in rural schools, who can make a meaningful contribution in urban schools. All they need is an opportunity to unleash their potential. This, however, does not imply that good teachers are not needed in rural schools

Equal access to English and an indigenous African language must be given to learners, and conditions be created for learners to be able to utilise these languages post matriculation. This could be done, perhaps, by offering bursaries to students who wish to pursue studies in these languages at tertiary level. Of course, the languages would also need to be tied to employment, e.g. making it compulsory for doctors to know a dominant indigenous African language in the region where they wish to serve. This would be in addition to, not instead of English. The idea here is that unless learners see the functional value in learning African languages, they might not be as strongly motivated to study the languages as they are to study English.

\section{References}

Afolayan, A. 1978. Towards an Adequate Theory of Bilingual Education for Africa. In J.J.E. Atalis (ed.). International Dimensions of Bilingual Education. Georgetown University Round Table on Languages and Linguistics, Washington, DC: Georgetown University Press, 330-390.

Banda, F. 2000. The Dilemma of the Mother Tongue: Prospects for Bilingual Education in South Africa. Language, Culture and Curriculum. Vol. 3. No. I. 5I-66.

Buthelezi, Q. 1995. South African Black English: Lexical and Syntactic Characteristics. In Mesthrie, R. 1995. 242-250. Language and Social History. Cape Town: David Phillip.

Department of Education. 2004. Language in Education Policy. 2004. Pretoria: Government Printer.

Department of Arts and Culture. 2002. National Language Policy Framework. 2002. Pretoria: Government Printer.

Fanon, F. 1967. Wretched of the Earth. New York: Grove Press.

Janks, H. 200I. Critical Literacy: Models, Methods and Motivation. Paper Presented at the $46^{\text {th }}$ International Reading Association Convention, New Orleans, Louisiana, April 29-May 4, 2001.

Krashen, S. D. 1987. Principles and Practice in Second Language Acquisition. London: Prentice Hall.

Luckett, K. 1992. National Additive Bilingualism. Report from the Medium of Instruction Sub-Group to the Language Policy Research Group. NEPI Working Paper. 1993. National Additive Bilingualism: Towards the Formulation of a Language Plan for South African Schools. Southern African Journal of Applied Language Studies, 2, I: 38-60.

Mncwango, E. M. 2007. Schools as fertile ground for the implementation of Multilingualism in South Africa. Unpublished D. Phil Thesis: University of Zululand.

Roy-Campbell, Z. M. 200I. Empowerment through Language: The African Experience, Tanzania and Beyond. Trenton, NJ: Africa World Press.

Wildsmith, R. L. 1992. Teacher Attitudes and Practices: a Correlational Study. Unpublished Ph.D. Thesis, University of London. 